\title{
Building Creative Industries by Bringing Local Potential to Develop Village Community of Economic Independence
}

\author{
Cindy Veronica ${ }^{1 *}$ Nina Nur Alfi Aulia ${ }^{1}$ Dinda Suci Al Aluf ${ }^{1}$ Amar Khan Ijtihad \\ Mudhaffar ${ }^{1}$ Arik Susanti ${ }^{1}$
}

${ }^{1}$ Faculty of Language and Art, Universitas Negeri Surabaya, Surabaya, Indonesia

*Corresponding author. Email: cindy.18018@mhs.UNESA.ac.id.

\begin{abstract}
Currently, rural communities need economic independence. By having economic independence, rural communities can improve their standard of living to create a prosperous society. With the potential of natural resources as a catfish center village that has not been maximized, the creative industry is an alternative that can help increase the income of the people of Tawangrejo Village, Turi District, Lamongan Regency. Therefore, creative industry training is held to help improve people's living standards. The methodology is qualitative. In this activity, the village community was given training on three ways of processing catfish into processed catfish floss, catfish sticks, and catfish crackers. In addition, village communities were also given training on marketing strategies through digital media and product branding training. Through this training, the production and marketing of processed catfish products are expected to be carried out sustainably and can penetrate the international market share so that the potential of Tawangrejo Village, Turi District, Lamongan Regency as a catfish center village can be optimized and the welfare and standard of living of the community can increase significantly.
\end{abstract}

Keywords: creative industry, catfish, village development.

\section{INTRODUCTION}

In a dynamic lifestyle, creativity is required to keep innovating and growing. Through creativity, someone can invent a product, service, or another new idea by relating it to something that already exists or creating something new which can enhance their community's quality of life. By having creativity, someone will be able to optimize their potential into something that has useful value. Nowadays, the creative industry has become the highlight because it provides a significant amount for the economic sector in Indonesia. According to the Central Bureau of Statistics (BPS) and the Bureau of Creative Economy (Bekraf), the creative industry or the one that is usually called creative economy (ekraf) is one of the strategic factors which contribute a significant amount to Indonesian economics matters. This industry, which was born from individual creativity, then again gives birth to many new job opportunities and improves the welfare of the surrounding community.

Tawangrejo Village is a part of Turi District Lamongan Regency which has almost the same problem as another village in Turi District. Turi District is popular as a big producer in fishery affairs, especially catfish in Lamongan Regency, East Java. The catfish ponds are often found in Tawangrejo Village, Turi District, Lamongan Regency, East Java. Those catfish ponds can be seen on every side of Tawangrejo Village. Almost every corner in Tawangrejo Village has catfish ponds. 290 hectares of the entire 351 hectares is catfish ponds, and the rest of them are residence, meadow, school, streets, and field. Automatically, this becomes the main job of Tawangrejo Village's resident, which is as a catfish farmer. The majority of Tawangrejo Village's residents live with an adequate amount and a modest lifestyle. In another word, Tawangrejo Village can be 
appointed as a prosperous village and not a left-behind village. The development of catfish that didn't reach the maximum state is one thing that disconcerted in this village.

Another thing is the new way to process the catfish which can increase the sale value has not been found. That is why as for the solution to this problem, creative industry training is needed so that the community's life level can be increased. Through the implementation of the Village Development Program (PHP2D) in Tawangrejo Village, Dewan Perwakilan Mahasiswa (DPM) FBS UNESA Team have designed activities and programs that will be carried out involving: This study would explain the development of creative industry in desa Tawangrejo to improve family income,

\section{LITERATURE REVIEW}

\section{1. Creative Industry}

\subsubsection{Definition, Background, and basic concept of the creative industry.}

The creative industry is part of the creative economy that involves individual abilities and skills in processing existing potential so that it is useful for everyone. Creative industry can be defined as an effort to utilize the creativity, skills, and talents of individuals who can generate added value, employment opportunities, and improve the quality of life for themselves and others [1]. Creative industry can also be interpreted as a breakthrough to optimize the economic activity of processing raw materials sourced from the creativity, skills, and talents of an individual who has the potential to gain profits and create jobs through the development and utilization of their capabilities and existing raw materials (UK DCMS Task Force, 1998). In the line with the statements, Indonesia's Ministry of Trade in 2007 define the creative industry as an economic activity that process materials using individual creativity, gift, and skills to create prosperity and employment for other individuals through producing and processing the available natural resources and the individual creativity.

In this 2000 era, Creative Industry has become one of the economic sources that have a crucial role in the world. According to John Howkins, who came up with this idea, argues that economic growth in the current era is determined by the creative and innovative ideas that emerge [2]. This can be seen from how the creativity of the younger generation with all the new ideas and innovations they possess plays a crucial role in the creative industry development. In addition, technological advances in the 21 st century also play an important role in the growth of the creative industry. This is happening since the increasingly sophisticated technology paired with the increasing use of social media makes it easier for them to communicate with each other, establish relationships, get inspiration, and support the distribution of ideas and creativity. From this, it can be said that technology development becomes a bridge for the young generation to objectify the ideas and innovation they possess. in short, the basic concept of the creative industry is a new business that focuses on creative ideas and knowledge, as well as individual innovation in creating a sales market for the products produced so that they can compete on international market platforms and can create new jobs to help maximize the existing potential.

\subsubsection{The role and benefits of the creative industry.}

The creative industry provides many benefits and roles towards maximizing the utilization of the existing potential to increase economic income. In their work, [3] agree that creative industries are considered as one of the most promising economic segments that play an important role to contribute to wealth and jobs creation. Quoting from Zurich.co.id, the creative industry has contributed $7 \%$ from the national PBD. PDB graph in 2010-2015, the development of creative industry has increased significantly by $6.89 \%$ in 2010 until $7.38 \%$ in 2015 , even though the increment was relatively small, it is shown that there is an escalation every year [4]. With the percentage mentioned before, it can be concluded that the creative industry in Indonesia can be a new power source to support the increase of the nation's economic development.

The existence of creative industry as an alternative to increasing social welfare surely cannot move independently, accumulation of some components including innovation, suggestion, idea, or creativity from the community is required. With the innovations arising, there is also a possibility where the creative business participant came to show up, this matter holds potential in making Indonesia as a country with the most worker in productive age so that will influence in increasing of living standards in economic sector later.

\section{1.3 Creative Industry in Indonesia.}

The creative industry began to show up in 2006 where the current president, Susilo Bambang Yudhoyono instructed to make development on the creative economy in Indonesia. Some kinds of creative industries in Indonesia can be classified as potential creativity that can help to increase the growth of Indonesian citizens. Those kinds of the creative industry in Indonesia are (1) Culinary, (2) Product Design, (3) Advertisement, (4) Game Development and Application, (5) Architecture, (6) Fashion, (7) Interior Design, (8) Visual Communication Design, (9) Performing Arts, (10) Film, Animation, and Video, (11) Photography, (12) Crafting, (13) Music, (14) Publishing, (15) Fine Arts, (16) Television and Radio. Those kinds of creative industry show that it is not only focused on one kind of business. More than that, this business has a tremendous opportunity with a wide range of business types. 
In Indonesia, the role of the creative industry has a big impact on the growth of the nation's economic sector. In 2016, the research result by the Bureau of Creative Economy (Bekraf) and the Central Bureau of Statistics (BPS) indicated that the contribution given by the existence of the creative industry in Indonesia towards the economic sector is by 922.59 billion rupiahs or $7.44 \%$ towards national Bruto Domestic Product (PDB) with the majority of the employee as many as one to four and with education level is dominated by the Junior High School graduate and below. In the existing data, there are three sub-sector that has the biggest role, that is culinary subsector $(50.14 \%)$, the Crafting sub-sector $(24.30 \%)$, and the fashion sub-sector (22.98\%) [2].

\subsection{Economic Independence}

According to the Merriam-Webster Dictionary, being independent means in a state of being able to stand alone; not dependent on others not requiring or relying on something else: not contingent [5]. In short, independence is a person's ability to think, feel and make decisions personally based on oneself rather than following what others believe.

Meanwhile, the term "economy" has several meanings. Based on Meeriam Webster Dictionary, "economy" is defined as the process or system by which goods and services are produced, sold, and bought in a country or region [6]. Furthermore, "economy" can sometimes refer to the institutions in the market as the most striking manifestation of efforts to achieve efficiency in the form of activities aimed at obtaining goods and services that become our needs.

Most experts have the same opinion that the economic independence of a country is the positive effect of the increasing function of its level of social and economic development explains that economic independence implies the establishment of an equitable, mutually advantageous, and fair international division of labor to promote balanced economic development [1]. In his work, Clarkson (1979:139) also defines economic independence as when the community has greater control over the production and capital accumulation process which can further be called "self-sufficiency in the production of the means of production [1]. From this, it can be said that economic independence is a manifestation of the ability of a community to manage, obtain, and fulfill the basic needs whether it is goods or services needs; without depending on others.

\section{METHODOLOGY}

There are two methods to develop the creative industry in Desa Tawangrejo, namely, socialization and workshop. The socialization and workshop are conducted in an attempt to educate the community of Tawangrejo village, Turi district, Lamongan regency about how to maximize the utilization of the potential resources in their village. Since the socialization and workshop are crucial in terms of achieving the objectives of this program, therefore the team of PHP2D DPM FBS UNESA decided to choose those two methods for this empowerment program.

The socialization is conducted to give insights to the community about the concepts of the program. In these steps, the team is going to provide information about some methods of increasing the value of the catfish and how to utilize technologies as a marketing media. This socialization is going to be held in the Tawangrejo village hall with the local youth organization and family welfare program members as the participants.

Furthermore, two workshops are also going to be conducted as the main methods of this program which is aimed to educate the community about processing and marketing catfish products. In this step, the team of PHP2D DPM FBS UNESA is planning to educate the community on how to make catfish products that are not only limited to the meat but also use the skin and the bone of the catfish to maximize the value of catfish. In this empowerment program, the team of PHP2D DPM FBS UNESA is going to educate the community to process the catfish to become some products to increase the value of the catfish itself. Some of those products are Keripik Kulit Lele, Abon Lele, and Stick Duri Lele. This workshop is also going to be conducted in Tawangrejo village hall with the local youth organization and family welfare program members as the participants.

Implementation of the Village Development Program (PHP2D) in Tawangrejo Village, the UNESA FBS DPM team has designed programs and activities to be carried out including Training on processed catfish floss, training on processed catfish skin crackers, and training processed Stick Duri Lele are processed into products that have high economic value. So this effort must be a sector that has the potential to be developed in Tawangrejo Village, due to the lack of innovation that utilizes catfish meat and waste (skin and bones). Not only as an optimization of the utilization of catfish, but the empowerment of skills like this can improve the economy of the local community by having more selling value when it is ready to be distributed in the market. So that it can improve the skills and economy of the community, this is done by providing skills to the community in the form of training and assistance by the PHP2D DPM FBS UNESA Team. 


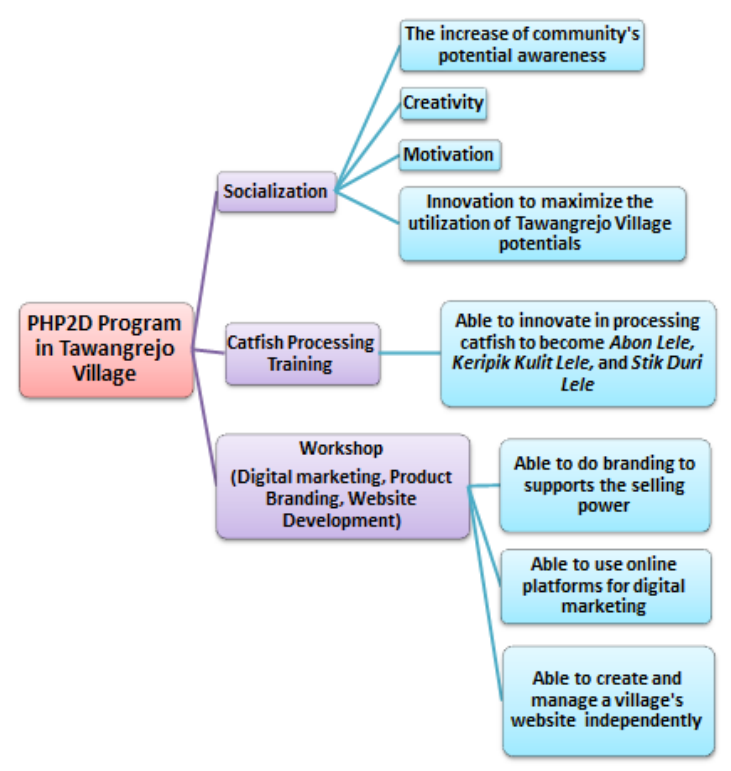

Figure 1. Activity Methodology

\section{RESULTS AND DISCUSSION}

The first step of this empowerment program is socialization. The result of holding the socialization stage as the first stage of this empowerment program is an increase in several things from the community, including awareness of their potential as well as creativity, motivation, and innovation to take advantage of these potentials.

Meanwhile, the workshop stage is conducted to create independence and community welfare in the marketing system for natural potential products in the village after the implementation of this program. In addition, a new source of economic will be formed which results are for village empowerment groups and also the community of Tawangrejo village themselves.

Furthermore, as mentioned before, several workshops are being conducted. The first is Digital Marketing Workshop. This workshop is creating an understanding of the community about product marketing digitally and making the community able to use online marketing platforms so that the marketing of processed catfish products is more widespread through ecommerce and later the community can get additional income through marketing their own managed products.

The second workshop is about A product branding workshop which in its implementation makes the community know and understand as well as practicing how to increase the selling value of a product through the selection of names, logos, brands, as well as product packaging that is appropriate and can support its selling power.
In addition to socialization and workshops, there is one more program held by the PHP2D DPM FBS UNESA team, namely catfish processing training. This program makes the community able to innovate in processing catfish into several processed catfish products by utilizing all parts of catfish from the meat to the bones. The processed products are, Abon Lele, Keripik Kulit Lele, and Stick Duri Lele. In addition, this program also makes the community is interested in always creating innovation in processing catfish into several products with high selling power which able to compete in national and even international markets.

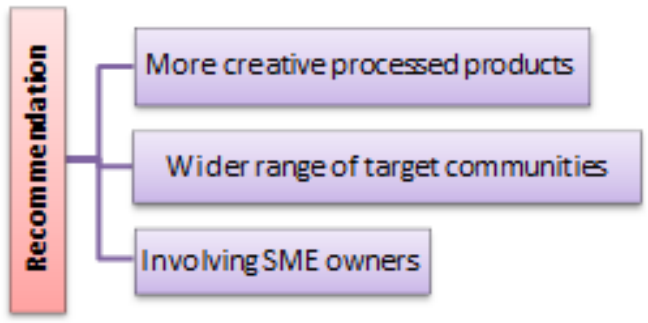

Figure 2. Recommendations

It is often found that catfish are sold immediately after harvest. Although the business of processed catfish is very promising, there are still few entrepreneurs who glance at the business opportunity of processed catfish to compete with other processed fish. Therefore, catfish can be created into various innovative foods to become better-processed products and have higher selling prices. Through the innovation of the creative industry of catfish processing, society's income can increase. This is in line with Suryana's statement in the book "Creative Economy, New Economy: Changing Ideas and Creating Opportunities", that the Creative Economy can encourage income creation, job creation, and export income. In addition, the creative economy can also encourage social aspects (social inclusion), cultural diversity, and human resource development. The creative economy is also a new economic concept that combines information and creativity by relying on ideas, suggestions, and knowledge from human resources as a factor of production. In economic studies, it is known that there are four factors of production, namely natural resources, human resources, capital (main factor), and orientation or management (Gusti, 2016). In the management of creative industries, it is necessary to have a division of tasks.

Therefore, in this case, PHP2D DPM FBS UNESA Team will form and assist an empowerment group consisting of representatives of PKK women, youth organizations, and Tawangrejo Village community then will be re-divided into two small groups, namely the production group and the marketing group. This article, it will be limited to catfish processing training. This program makes the community able to innovate in 
processing catfish into several processed catfish products by utilizing all parts of catfish from the meat to the bones. The processed products are, Abon Lele, Keripik kulit Lele, and Stick Duri Lele. Technical training can be described as follows:

\section{a. Abon Lele}

The training activity for making Abon fish was attended by an empowerment group that consist of representatives from PKK women, youth organizations, and residents. The implementation of this shredded-making training takes approximately 5 hours. Supporting equipment will be provided so that training participants do not need to spend any money. The practice of making Abon fish is divided into 3 groups. Each group consists of 5 members who have their respective tasks such as processing steamed fish, making spices, sautéing fish with spices until it becomes shredded. After this training, it is expected to be able to share the knowledge obtained with the management and other PKK women, and the local community, as well as be able to improve the economy of the local villagers.

The process of making Abon Lele is not much different from the process of making Abon beef. Here is the process of making Abon Lele: (1) The catfish is cleaned and the dirt in its stomach is removed, (2) Separate the catfish from the skin, then steam the catfish until cooked, (3) After cold, separate the meat from the bones, and finely chopped, (4) Heat the oil and fry the spices that have been prepared until cooked, (5) After cooked, add the chopped catfish, (6) Then cook the Abon until dry by using low heat, (7) Abon Lele is ready to be packed.

b. Keripik kulit Lele

In the processing of catfish, of course, we only need the meat. While the skin will be wasted if it is not converted into a more varied process of catfish In addition, fish skin tends not to be used in the production of a fish meal because its texture is difficult to crush and process into flour. Meanwhile, if fish skin waste is disposed of, it can cause environmental pollution, because the protein content in fish skin is still relatively high and destroys the beauty of the environment because it causes an unpleasant odor. One of the uses of fish skin is to be processed into fish skin crackers. The practice of making Keripik kulit Lele is divided into 3 groups. Each group consists of 5 members who have their respective tasks such as separating the skin from the meat, cleaning the skin, and processing until the catfish crackers are ready to be fried. The training needs approximately 4 hours. In this training, supporting equipment will be provided, so that training participants do not need to spend any money.

In making catfish skin into Keripik kulit Lele, or better known as catfish rambak, it takes a longer time to produce. Here is the process of producing Keripik kulit Lele: (1) Clean the catfish skin that has been separated from the meat, (2) Cut the catfish skin to the size that you want, (3) The spices that have been prepared are mashed, then mixed with the catfish skin, (4) Catfish skin that has been seasoned is left for 15 minutes, (5) Add the catfish skin to the flour and egg mixture, (6) Then stir until all parts of the catfish skin are covered with flour, (7) Fry catfish skin until golden yellow, (8) Keripik kulit Lele are ready to be packed.

c. Stick Duri Lele

This program is filled with providing the introduction material to the empowerment group about how to process the catfish thorn. Fishbone processing is conducted as a way to maximize the catfish abundance potential in Tawangrejo Village. In addition, this program aims to improve the local income by increasing their creativity to create a new product by utilizing their potential village as the catfish center village. While conducting this program, there will be two sessions that consist of, first, the material presented about how to make catfish spine stick by the PHP2D DPM team, and the second is the demonstration about the way to make Stick Duri Lele. This program is expected to be useful for the residents and the housewives in Tawangrejo Village to help them increase the home industry competitiveness to help them increase their income for a better life.

In this program, we strive to utilize all the parts of catfish to be processed. That's why, not only processing the meat and the skin, the thorns are also utilized to be processed as delicious snacks which we call as "Stick Duri Lele". The process of making Stick Duri Lele is simpler than the process of making the other two products. Here are the process of how to make Stick Duri Lele: (1) Clean the catfish's thorn that has been separated from its meat, (2) Cook the catfish's thorn using a pressure cooker to make the thorn to be soft, (3) Let the soft thorns to cool down for a while, (4) Puree them using a blender and add some spices, (5) Pour the blend into a bowl and add the flour, mix them evenly, (6) Flatten the dough and cut it to the desired size, (7) Fry it until it turns golden, (8) Stick Duri Lele are ready to be packed.

After that, we will conduct a workshop about how to package, administration/bookkeeping, and sale of processed catfish products to the wider community through the website, e-commerce and social media.

\section{CONCLUSION}

To sum up, the creative industry is required to improve family income to achieve empowerment of the village. Hence, the role of the young generation, such as team PHP2D DPM FBS, could help society to make its goal achieved. It can be said that the local people play an important role as the ones who will be responsible to continue the action which has been prepared and planned by the team of PHP2D. With the participation from the local people, thus in executing this program PHP2D team will need some information related to the potency or the problems about the environment in the targeted village. As a consequence, the participation of the local people and the support from the local government will be the second most important factor that determine the fruitfulness of the Village Empowerment Program (PHP2D). When the participation of the local and the involvement of local government is achieved, therefore 
the next things to do is to conduct a training and counseling. The training and the counseling will be used as the core instrument of the program.

\section{REFERENCES}

[1] Badrudin, R., Siregar, B. (2018). Creative economy development based on triple helix in Indonesia. $1(17)$, 82-91. https://doi.org/10.14505/tpref.v9.1(17).09.

[2] Hidayat, AR., Asmara. A. Y. (2017). The creative industry in supporting economic growth in Indonesia: Perspective of regional innovation system Creative industry in supporting economic growth in Indonesia: Perspective of the regional innovation system

[3] Kimpeler, S., \& Georgieff, P. (n.d.). 13 . The roles of creative industries in regional innovation and knowledge transfer - The Case of Austria. 207219.

[4] Al-rahmani, E. (1988). University of New Hampshire Scholars , Repository Economic independence: Concepts and strategies, a theoretical investigation and an empirical case study.

[5] Bisnis, D. A., Ilmu, F., Politik, I., Ad, J., \& Ad, J. (2017). Activation Of Creative Sub-Economic Sector In Bandung City Ria Arifianti and Mohammad Benny Alexandri Aktivasi Sub-Sektor Ekonomi Kreatif Di Kota Bandung. 2(3), 201-209.

[6] Poernomo, B., Maulina, A., Bandi, A. A., \& Sandra, J. (2021). The Importance of Creativity and Innovation in Maintaining Business in the Pandemic Situation : A Case Study of Micro Small and Medium Enterprises ( MSME ) Managed by Millennial Groups in Jakarta. 6357-6367. 